\title{
PENERAPAN PENDEKATAN CONCRETE-REPRESENTATIONAL-ABSTRACT (CRA) BERBASIS INTUISI UNTUK MENINGKATKAN KEMAMPUAN KOMUNIKASI MATEMATIK SISWA SMP
}

\author{
Memen Permata Azmi \\ Pendidikan Matematika Universitas Islam Negeri Sultan Syarif Kasim Riau \\ Email: memen.permata.azmi@uin-suska.ac.id
}

\begin{abstract}
This research is a quasi-experimental with nonequivalent pretest-posttest control group design by using Concrete-Representational-Abstract (CRA) based on intuition approach and Conventional Learning $(C L)$ conducted to investigate enhancement of students mathematical communication ability. Population of the research is seventh grade students in one of the Junior High School in Kampar district Riau Province, amounting to 175 students. The sampling research using purposive sampling techniques to choose two classes totaling 66 students who homogeneous characteristics. Before the experiment, the students are classified into high, medium, and low level of prior mathematical ability. The instruments of research are daily test results and a mathematical communication ability test. The research found that the enhancement mathematical communication ability of students who received CRA based on intuition approach are better than those of students who recieved CL reviewed based on overall students, students of high level prior mathematical ability, students of medium level prior mathematical ability, and students of low level prior mathematical ability. Other findings, there are differences in enhancement mathematical communication ability of students between level of prior mathematical ability (high, medium, and low) who received CRA based on intuition approach
\end{abstract}

Keywords: CRA approach, intuition, mathematical communication ability

\section{PENDAHULUAN}

Kemampuan siswa dalam menyelesaikan masalah matematika. Pemerintah Indonesia menetapkan tujuan pembelajaran matematika untuk pendidikan dasar dan menengah yang dikemukakan Depdiknas (2006) yaitu salah satunya agar siswa dapat mengkomunikasikan gagasan dengan simbol, tabel, diagram atau media lain untuk memperjelas masalah. National Council of Teacher of Mathematics (NCTM) (2000) sebelumnya juga menyatakan tentang prinsip dan standar matematika di sekolah salah satunya adalah agar siswa memiliki kemampuan komunikasi matematik.

Menurut Turmudi (2008) Komunikasi adalah bagian yang esensial dalam matematika dan pendidikan matematika karena aktivitas berkomunikasi merupakan cara untuk saling bertukar gagasan dan mengklarifikasi pemahaman. Proses komunikasi membantu membangun makna dan kelengkapan gagasan dan membuat hal ini menjadi milik publik. Ketika siswa diminta berargumentasi untuk mengkomunikasikan hasil pemikirannya kepada orang lain secara lisan atau tertulis, mereka belajar untuk menjelaskan atau meyakinkan orang lain, mendengarkan gagasan atau 
penjelasan orang lain, dan memberikan kesempatan kepada siswa untuk mengembangkan pengalaman mereka. Dengan kata lain refleksi dan komunikasi merupakan proses yang saling berkaitan dalam belajar matematika. Lebih lanjut Turmudi (2009) menyatakan siswa memiliki keuntungan ganda berkomunikasi pada pelajaran matematika karena mereka berkomunikasi untuk belajar matematika dan mereka belajar berkomunikasi secara matematika. Dipihak lain Walle (2006) mengemukakan standar kemampuan komunikasi menitikberatkan pada pentingnya dapat berbicara, menulis, menggambar, dan menjelaskan konsepkonsep matematika. Belajar berkomunikasi dalam matematika membantu perkembangan interaksi dan pengungkapan ide-ide dalam kelas karena siswa belajar dalam suasana yang aktif.

Berkomunikasi matematik secara umum dapat diartikan sebagai berkomunikasi untuk belajar matematika yaitu dalam pembelajaran siswa melakukan kegiatan berbicara, menulis, mendengarkan, dan berdiskusi berdasarkan pola komunikasi dua arah dan tiga arah. Selanjutnya belajar berkomunikasi secara matematika yaitu siswa menggunakan objek-objek matematika yaitu angka, gambar atau gambar geometri, simbol-simbol, grafik dan lain sebagainya dalam menyusun ide-ide dan menyelesaikan masalah matematika.

Ernest (dalam Dahlan, 2011) membedakan komunikasi matematika menjadi dua jenis yakni komunikasi matematika verbal dan non verbal. Lebih rinci Mahmudi (2009) juga membagi komunikasi matematika yaitu komunikasi tertulis dan lisan. Komunikasi matematika tertulis dapat berupa penggunaan kata-kata, gambar, tabel, dan sebagainya yang menggambarkan proses berpikir siswa. Komunikasi tertulis juga dapat berupa uraian pemecahan masalah atau pembuktian matematika yang menggambarkan kemampuan siswa dalam mengorganisasi berbagai konsep untuk menyelesaikan masalah. Sedangkan komunikasi matematika lisan dapat berupa pengungkapan dan penjelasan verbal suatu gagasan matematika. Komunikasi lisan dapat terjadi melalui interaksi antar siswa misalnya dalam pembelajaran dengan diskusi kelompok. Siswa perlu dibiasakan mengkomunikasikan secara lisan maupun tulisan idenya kepada orang lain sesuai dengan penafsirannya. Melalui kegiatan tersebut siswa mendapatkan pengertian yang lebih bermakna baginya tentang apa yang sedang ia lakukan.

Pengembangan kemampuan komunikasi matematik berhubungan dengan hakekat matematika yang dikemukakan Sumarmo (2013) yaitu matematika sebagai bahasa simbol yang efisien, padat makna, memiliki sifat keteraturan yang indah dan kemampuan analisis kuantitatif, selain itu mayematika bersifat universal dan dapat dipahami oleh setiap orang, serta membantu menghasilkan model matematika yang diperlukan dalam memecahkan masalah berbagai cabang ilmu pengetahuan dan masalah kehidupan sehari-hari. Memiliki kemampuan komunikasi matematik bagi siswa sangat penting, hal tersebut dikemukakan Asikin (Yonandi, Sumarmo, 2013) bahwa kemampuan komunikasi matematik membantu siswa dalam menajamkan cara berpikir, sebagai alat untuk menilai pemahaman siswa, membantu siswa mengorganisasikan pengetahuan matematik mereka, membantu siswa membangun pengetahuan 
matematiknya, meningkatkan kemampuan pemecahan masalah matematik, memajukan penalarannya, membangun kemampuan diri, meningkatkan keterampilan sosialnya, serta bermanfaat dalam mendirikan komunitas matematika. Disamping itu, Collins (dalam Asikin, 2002) menyatakan salah satu tujuan yang ingin dicapai dalam pembelajaran matematika adalah memberikan kesempatan seluasluasnya kepada siswa untuk mengembangkan dan mengintegrasikan keterampilan komunikasi melalui lisan dan tulisan, pemodelan, speaking, writing, talking, drawing serta merepresentasi apa yang telah dipelajari.

$$
\text { Bagi siswa melakukan }
$$

komunikasi matematik bukan hal yang mudah karena proses berpikir siswa tidak dapat secara langsung tertangkap panca indera, agar dapat diamati siswa perlu berlatih berkomunikasi secara matematika baik lisan maupun tertulis. Kenyataannya dari studi pendahuluan di salah satu SMP Negeri di Kabupaten Kampar, ditemukan rendahnya kemampuan komunikasi matematik siswa khususnya mengenai komunikasi tertulis matematik. Hasil penelitianpenelitian terdahulu juga mengindikasikan rendahnya kemampuan komunikasi matematik siswa. Penelitian Lindawati (2010) menunjukkan bahwa kemampuan komunikasi matematik siswa SMP masih rendah karena persentase rerata skor siswa hanya mencapai $41 \%$ dari skor ideal. Fakta lain dari penelitian Mikrayanti (2012) menyimpulkan bahwa kemampuan komunikasi matematik siswa SMP juga masih belum memuaskan karena persentase rerata skor siswa hanya mencapai $51,75 \%$ dari skor ideal.

Walaupun secara eksplisit diamanatkan dalam kurikulum namun dalam pelaksanaannya metode pembelajaran dan bahan ajar yang digunakan tidak fokus pada pengembangan kemampuan komunikasi matematik, sehingga kurang memfasilitasi siswa dalam melakukan komunikasi matematik. Hal ini mengindikasi bahwa tujuan pembelajaran matematika yang sesuai dengan kurikulum belum tercapai secara maksimal.

Perlu mempertimbangkan aspekaspek yang dapat meningkatkan kemampuan komunikasi matematik siswa yaitu pendekatan pembelajaran, materi pelajaran, sarana dan prasarana, serta tingkat kognitif yang cocok bagi siswa. Hal ini sesuai dengan yang dikemukakan Trianto (2011) bahwa dalam dalam memilih suatu model pembelajaran harus memiliki pertimbangan-pertimbangan. Jadi, dalam mendesain pembelajaran harus memegang prinsip kesesuaian antara pendekatan pembelajaran yang digunakan dengan materi pelajaran serta mampu memfasilitasi siswa yang berkemampuan tinggi, sedang, atau rendah terlatih menggunakan komunikasi.

Diduga, pembelajaran matematika yang paling memungkinkan untuk meningkatkan kemampuan komunikasi matematik adalah menggunakan pendekatan Concrete Representational Abstract (CRA). Pada pendekatan CRA terdapat tahapan konkret serta abstrak, mengindikasikan bahwa pendekatan $C R A$ cocok diimplementasikan pada siswa SMP. Ditahap perkembangan kognitif siswa SMP, operasi matematika berada pada antara tahap operasi konkret yaitu memahami operasi logis menggunakan benda konkret menuju tahap operasi formal yaitu siswa mulai mampu bernalar menggunakan hal-hal yang abstrak. Hal tersebut diperkuat dari penyataan Sumarmo (2013) bahwa 
sesuai dengan tahap perkembangan kognitif sebagian besar siswa SMP/MTs yang berada pada tahap operasi konkret, tuntutan terhadap pemahaman dan penalaran masih terbatas pada produk dan proses matematika dalam dunia nyata atau dapat diilustrasikan melalui contoh-contoh nyata. Selanjutnya untuk siswa mulai dari kelas akhir SMP/MTs, pengenalan, pemahaman, dan penalaran siswa terhadap produk dan proses matematika secara bertahap mulai dari bentuk-bentuk konkret meningkat ke bentuk-bentuk formal.

Hal tersebut sesuai dengan yang dikemukakan Witzel (2005) bahwa pendekatan $C R A$ tahap pembelajarannya dimulai dari tahap konkret, siswa diajak mengenal atau menemukan konsep secara langsung melalui alat peraga manipulatif dari benda konkret, dilanjutkan dengan tahap representasi bergambar dari manipulasi benda konkret dan diakhiri pada tahap ketiga yaitu menyelesaikan masalah matematik secara tidak langsung menggunakan notasi abstrak. Tahap konkret dengan tahap abstrak adalah dua hal yang sangat berbeda atau terpisah tetapi dapat dihubungkan menggunakan tahap representasi. Keterkaitan antara tahap representasi dengan komunikasi matematik menurut Sumarmo (2013) dan Baroody (dalam Pujiastuti, 2014) adalah tahap representasi merupakan bagian dari komunikasi matematik.

Pendekatan CRA dilandasi pada teori Jorome Bruner pada tahun 1960. Bruner (dalam Sumarmo, 2013) menyatakan terdapat tiga tahap pembentukan pengetahuan baru pada siswa, yaitu: tahap enaktif (tahap Konkret), tahap ikonik (tahap representasi), dan tahap simbolik, (tahap Abstrak). Selain itu, pendekatan didasarkan pada teori tahap perkembangan kognitif Piaget. Siswa SMP tahap perkembangan kognitifnya berada pada tahap operasi konkret dan operasi formal karena kecepatan tingkat kognitif siswa yang berbeda. Secara garis besar Piaget (dalam Suparno, 2001) menjelaskan bahwa tahap operasi konkret ditandai dengan penggunaan aturan logis atau sistematis yang jelas yang diterapkan pada masalah-masalah konkret, sedangkan tahap operasi formal ditandai dengan pemikiran yang abstrak, hipotesis, induktif serta deduktif serta dalam berpikir, anak tidak dibatasi lagi pada kejadian-kejadian konkret.

Pada dasarnya mempelajari matematika membutuhkan benda konkret sebagai perantara untuk mencapai konsep matematika yang abstrak. Hal tersebut sejalan dengan pernyataan Suherman, dkk. (2001) bahwa konsep abstrak yang baru dipahaminya itu akan mengendap, melekat, dan tahan lama bila ia belajar melalui berbuat dan pengertian, bukan hanya melalui mengingat-ingat fakta. Artinya pembelajaran matematika menggunakan benda konkret memiliki peran penting dalam menciptakan kekonkretan.

Beberapa penelitian pembelajaran matematika menggunakan pendekatan CRA dilakukan oleh Yuliawati (2011), Rahmawati (2013) dan Yuliati (2013) memberikan hasil bahwa penerapan $C R A$ dalam pembelajaran matematika dapat meningkatkan kemampuan matematik siswa. Witzel (2005) menyatakan pendekatan $C R A$ berhasil diterapkan dalam pembelajaran dari pengaturan kelompok kecil sampai klasikal serta bermanfaat bagi siswa yang memilki dan tidak memiliki kesulitan belajar. Artinya, jika ditinjau dari tingkat kemampuan matematika siswa, menggunakan pendekatan $C R A$ pada pembelajaran matematika dapat memfasilitasi siswa berkemampuan tinggi, sedang, dan rendah. 
Aktivitas lain yang perlu kehadirannya dalam pembelajaran matematika yaitu intuisi. Secara umum intuisi adalah proses mendapatkan sesuatu secara langsung/tiba-tiba, tidak memerlukan referensi atau pembuktian berdasarkan fakta-fakta (deduktif) terkadang memerlukan pertimbangan empiris (induktif) namun hasilnya dianggap sebagai sebuah kebenaran. Pentingnya melibatkan intuisi dalam pembelajaran matematika dinyatakan Dahlan (2011) bahwa secara khusus dalam matematika, anak harus memahami bahwa penalaran intuisi, penalaran induktif dan pendugaan, serta pembuktian logis atau penalaran deduktif memainkan peran yang penting, mereka harus menyadari atau dibuat sadar bahwa intuisi merupakan dasar kemampuan tingkat tinggi dalam matematika dan juga ilmu pengetahuan lainnya.

Usodo (2012) memberikan gambaran bahwa pembelajaran matematika saat ini masih didominasi pada pengembangan kognisi formal, akibatnya matematika menjadi tampak seperti barang asing yang tidak ada hubungannya dengan pengetahuan informal siswa sehingga siswa tidak diberi kesempatan untuk munculnya intuisi. Hasil penelitian Burton tahun 1999 (dalam Sukmana, 2011) memberikan hasil 83\% siswa mengakui bahwa kehadiran intuisi membantu mereka dalam bermatematika dengan kadar yang beragam. Sejalan dengan pendapat Sukmana (2011) bahwa jika kekuatan intuitif yang dimiliki siswa diabaikan bagaimanapun terus mempengaruhi kemampuan siswa bematematika. Bila berpikir intuitif tidak dikendalikan juga dapat menggangu proses berpikir matematis. Jika aspek formal diabaikan maka siswa cenderung akan mengandalkan hanya pada argumen intuitif, dan apa yang akan diajarkan bukanlah matematika. Artinya dalam mengajarkan matematika perlu melibatkan aspek matematika formal dan intuitif sesuai bagiannya masingmasing demi tercapainya tujuan pembelajaran matematika.

Penerapan pendekatan CRA berbasis intuisi yang dimaksud adalah pada setiap awal pembelajaran sebelum melalui tahap konkret, representasi dan abstrak terlebih dahulu diberi tahap intuitif. Pada tahap intuitif siswa diberikan permasalah yang dijawab secara langsung sebagai pemicu jawaban formal yang akan ditunjukkan melalui tahap $C R A$. Melibatkan tahap intuitif dalam pendekatan $C R A$ diharapkan dapat meningkatkan kemampuan komunikasi matematik karena aktivitas merepresentasi dalam bentuk gambar, diagram, bahasa atau simbol matematik, atau model matematika diduga memerlukan bantuan intuisi.

Selain faktor pembelajaran menggunakan pendekatan $C R A$ berbasis intuisi dan konvensional (PK), ada faktor lain yang diduga dapat mendorong peningkatan kemampuan komunikasi matematik yaitu Kemampuan Awal Matematik (KAM). Jadi penyelidikan kemampuan komunikasi matematik siswa pada penelitian ini juga dikaji berdasarkan KAM siswa berkemampuan tinggi, sedang, dan rendah.

Berdasarkan latar masalah yang telah diuraikan, maka penelitian ini akan menyelidiki apakah peningkatan kemampuan komunikasi matematik siswa yang menggunakan pendekatan $C R A$ berbasis intuisi lebih baik dari pada siswa yang menggunakan PK ditinjau berdasarkan keseluruhan siswa dan masing-masing KAM siswa (tinggi, sedang, dan rendah)? Dan apakah terdapat perbedaan peningkatan 
kemampuan komunikasi matematik siswa antar tingkat KAM (tinggi, sedang, dan rendah) yang menggunakan pendekatan $C R A$ berbasis intuisi?

\section{METODE PENELITIAN}

Penelitian ini merupakan penelitian eksperimen semu dengan desain Nonequivalent Pretest-Posttest Control Group Design yang dinyatakan Cresswell (2010). Secara singkat desain penelitian tersebut disajikan pada Gambar 1.

$\mathrm{X} \quad \mathrm{O}$

$\mathrm{O}$

Gambar 1. Nonequivalent Pretest-Posttest Control Group Design

Keterangan:

$\mathrm{O} \quad=$ Pretest $=$ Posttest $($ Kemampuan komunikasi)

$\mathrm{X} \quad=$ Pendekatan $C R A$ berbasis intuisi

Penelitian ini dilaksanakan di salah satu SMP di Kabupaten Kampar Riau dengan melibatkan 66 siswa SMP kelas VII yang kemudian dibagi menjadi dua kelas yaitu kelas CRA berbasis intuisi dan kelas Konvensional dengan jumlah masing-kelas sebanyak banyak 33 orang. Pemilihan siswa kelas VII karena mereka merupakan kelas awal pada tingkat sekolah menengah pertama yang tingkat perkembangannya sebagian besar berada pada masa peralihan dari tahap operasi konkret ke tahap operasi formal.

Instrumen penelitian yaitu nilai rerata tes harian matematika sebanyak tiga kali untuk menentukan Kemampuan Awal Matematik (KAM) siswa sebelum pelaksanaan penelitian berlangsung di kelas. Kriteria pengelompokan siswa berdasarkan KAM dirujuk dari Sumarmo (2013) dengan beberapa modifikasi yang disajikan pada tabel 1 .

Tabel 1. Kriteria Pengelompokan Sampel Penelitian Berdasarkan KAM

\begin{tabular}{|c|c|}
\hline Rerata Tes Harian $(\mathbf{X})$ & Kategori \\
\hline $\mathrm{X} \geq 75 \%$ & Siswa dengan KAM Tinggi \\
\hline $60 \% \leq \mathrm{X}<75 \%$ & Siswa dengan KAM Sedang \\
\hline $\mathrm{X}<60 \%$ & Siswa dengan KAM Rendah \\
\hline
\end{tabular}

Instrumen lain yang digunakan adalah tes kemampuan komunikasi matematik (KKM) yang diberikan sebelum perlakuan sebagai pretest dan setelah perlakuan sebagai posttest pada kedua kelas. Dari tes tersebut diperoleh data peningkatan kemampuan komunikasi matematik. Besarnya peningkatan kemampuan tersebut dihitung menggunakan rumus gain ternormalisasi (Normalized gain) yang dikembangkan Hake (1999), yaitu:

$$
\text { N-Gain }(g)=\frac{\% \text { skor posttest }-\% \text { skor pretest }}{100-\% \text { skor pretest }}
$$


ISSN 2089-8703 (Print) Vol. 6, No. 1 (2017)

ISSN 2442-5419 (Online)

Hasil perhitungan N-Gain klasifikasi pada tabel 2.

diinterpretasikan menggunakan

Tabel 2. Klasifikasi $N$-Gain $(g)$

\begin{tabular}{|c|c|}
\hline N-Gain $(\mathbf{g})$ & Klasifikasi \\
\hline$g \geq 0,7$ & Tinggi \\
\hline$g \geq 0,7$ & Tinggi \\
\hline$g \geq 0,7$ & Tinggi \\
\hline
\end{tabular}

Data peningkatan kemampuan komunikasi matematik dianalisis secara statistik parametrik menggunakan uji $\mathrm{t}$ karena data berditribusi normal dan bervariansi homogen. Uji non parametrik juga digunakan yaitu uji Mann-Whitney U dan uji KruskalWallis karena data tidak berdistribusi normal.

\section{HASIL PENELITIAN DAN PEMBAHASAN}

Deskripsi data KAM, hasil pretest, posttest, dan N-gain kemampuan komunikasi matematik berdasarkan pembelajaran dan keseluruhan siswa serta masing-masing KAM (tinggi, sedang, rendah) disajikan pada Tabel 3

Tabel 3. Deskripsi Data Kemampuan Komunikasi Matematik

\begin{tabular}{|c|c|c|c|c|c|c|c|c|c|}
\hline \multirow{2}{*}{ KAM } & \multirow{2}{*}{ Stat. } & \multicolumn{4}{|c|}{$C R A$ berbasis intuisi } & \multicolumn{4}{|c|}{ PK } \\
\hline & & Pretest & Posttest & $g$ & $\mathbf{N}$ & Pretest & Posttest & $g$ & $\mathbf{N}$ \\
\hline \multirow{3}{*}{ Tinggi } & $\overline{\mathrm{x}}$ & 5,00 & 12,36 & 0,73 & \multirow{3}{*}{11} & 6,18 & 9,55 & 0,34 & \multirow{3}{*}{11} \\
\hline & $\% \overline{\mathrm{x}}$ & 33,33 & 82,4 & 73 & & 41,2 & 63,66 & 34 & \\
\hline & $\mathrm{S}$ & 1,90 & 2,66 & 0,27 & & 2,48 & 2,16 & 0,28 & \\
\hline \multirow{3}{*}{ Sedang } & $\overline{\mathrm{x}}$ & 4,00 & $\begin{array}{l}9,57 \\
\end{array}$ & 0,51 & \multirow{3}{*}{14} & 3,07 & 4,80 & 0,12 & \multirow{3}{*}{15} \\
\hline & $\% \overline{\mathrm{x}}$ & 26,67 & 63,8 & 51 & & 20,46 & 32 & 12 & \\
\hline & $\mathrm{S}$ & 2,48 & 3,27 & 0,25 & & 2,52 & 1,90 & 0,19 & \\
\hline \multirow{3}{*}{ Rendah } & $\overline{\mathrm{x}}$ & 2,62 & 7,75 & 0,42 & \multirow{3}{*}{8} & 2,43 & 4,71 & 0,16 & \multirow{3}{*}{7} \\
\hline & $\% \overline{\mathrm{x}}$ & 17,47 & 51,67 & 42 & & 16,2 & 31,4 & 16 & \\
\hline & $\mathrm{S}$ & 1,19 & 2,91 & 0,21 & & 2,07 & 1,11 & 0,16 & \\
\hline \multirow{3}{*}{ Keseluruhan } & $\overline{\mathrm{x}}$ & 4,00 & 10,06 & 0,56 & \multirow{3}{*}{33} & 3,97 & 6,36 & 0,20 & \multirow{3}{*}{33} \\
\hline & $\% \overline{\mathrm{x}}$ & 26,67 & 67,07 & 56 & & 26,47 & 42,4 & 20 & \\
\hline & $\mathrm{S}$ & 2,18 & 3,42 & 0,27 & & 2,84 & 2,91 & 0,23 & \\
\hline & & $\begin{array}{l}\mathrm{Ksin} \\
\mathrm{Sk}\end{array}$ & leal $p$ & 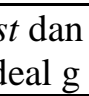 & & dalah & & & \\
\hline
\end{tabular}

Ringkasan hasil pengujian menjawab permasalahan penelitian ini statistik yang digunakan untuk disajikan pada Tabel 4, 5, 6, 7 dan 8.

Tabel 4. Hasil Uji Perbedaan Peringkat Data Peningkatan Kemampuan Komunikasi Matematik Ditinjau Berdasarkan Keseluruhan Siswa

\begin{tabular}{|c|c|c|c|c|c|}
\hline Pembelajaran & Rerata & $\begin{array}{c}\text { Mann-Whitney } \\
\mathbf{U}(\mathbf{Z})\end{array}$ & $\begin{array}{c}\text { Sig. (1- } \\
\text { tailed })\end{array}$ & $\mathbf{H}_{\mathbf{0}}$ & Kesimpulan \\
\hline $\begin{array}{c}\text { CRA berbasis } \\
\text { intuisi }\end{array}$ & 0,56 & $-4,960$ & 0,000 & Ditolak & lebih baik \\
\hline PK & 0,20 & & & \\
\hline
\end{tabular}


ISSN 2089-8703 (Print) Vol. 6, No. 1 (2017)

ISSN 2442-5419 (Online)

Tabel 5. Hasil Uji Perbedaan Rerata Data Peningkatan Kemampuan Komunikasi Matematik Ditinjau Berdasarkan Siswa dengan KAM Tinggi

\begin{tabular}{|c|c|c|c|c|c|}
\hline Pembelajaran & Rerata & $\mathbf{t}$ & $\begin{array}{c}\text { Sig. (1- } \\
\text { tailed) }\end{array}$ & $\mathbf{H}_{\mathbf{0}}$ & Kesimpulan \\
\cline { 1 - 2 } $\begin{array}{c}\text { CRA berbasis } \\
\text { intuisi }\end{array}$ & 0,73 & \multirow{2}{*}{3,347} & 0,001 & Ditolak & lebih baik \\
\cline { 1 - 2 } & 0,34 & & & \\
\hline
\end{tabular}

Tabel 6. Hasil Uji Perbedaan Peringkat Data Peningkatan Kemampuan Komunikasi Matematik Ditinjau Berdasarkan Siswa dengan KAM Sedang

\begin{tabular}{|c|c|c|c|c|c|}
\hline Pembelajaran & Rerata & $\begin{array}{c}\text { Mann-Whitney } \\
\mathbf{U}(\mathbf{Z})\end{array}$ & $\begin{array}{c}\text { Sig. (1- } \\
\text { tailed })\end{array}$ & $\mathbf{H}_{\mathbf{0}}$ & Kesimpulan \\
\cline { 1 - 3 } $\begin{array}{c}\text { CRA berbasis } \\
\text { intuisi }\end{array}$ & 0,51 & $-3,955$ & 0,000 & Ditolak & lebih baik \\
\cline { 1 - 2 } PK & 0,12 & & & \\
\hline
\end{tabular}

Tabel 7. Hasil Uji Perbedaan Rerata Data Peningkatan Kemampuan Komunikasi Matematik Ditinjau Berdasarkan Siswa dengan KAM Rendah

\begin{tabular}{|c|c|c|c|c|c|}
\hline Pembelajaran & Rerata & $\mathbf{t}$ & $\begin{array}{c}\text { Sig. (1- } \\
\text { tailed })\end{array}$ & $\mathbf{H}_{\mathbf{0}}$ & Kesimpulan \\
\cline { 1 - 2 } $\begin{array}{c}\text { CRA berbasis } \\
\text { intuisi }\end{array}$ & 0,42 & \multirow{2}{*}{2,643} & 0,01 & Ditolak & lebih baik \\
\cline { 1 - 2 } & 0,16 & & & \\
\hline
\end{tabular}

Tabel 8. Hasil Uji Kruskal-Wallis Data Peningkatan Kemampuan Komunikasi Matematik Siswa antar Tingkat KAM pada Kelas $C R A$ Berbasis Intuisi

\begin{tabular}{|c|c|c|c|c|}
\hline KAM & Rerata & Sig. & $\mathbf{H}_{\mathbf{0}}$ & Kesimpulan \\
\cline { 1 - 2 } Tinggi & 0,73 & \multirow{2}{*}{0,044} & Ditolak & $\begin{array}{c}\text { Terdapat perbedaan peringkat } \\
\text { peningkatan kemampuan } \\
\text { kemunikasi antar tingkat KAM }\end{array}$ \\
\cline { 1 - 2 } Redang & 0,51 & 0,42 & &
\end{tabular}

Berdasarkan tabel 4, ditinjau dari keseluruhan siswa, hasil penelitian ini menunjukkan peningkatan kemampuan komunikasi matematik siswa yang mendapatkan pendekatan $C R A$ berbasis intuisi secara signifikan lebih baik dari pada siswa yang mendapatkan pembelajaran konvensional. Berdasarkan klasifikasi peningkatan (gain) menurut Hake, peningkatan kemampuan komunikasi matematik siswa pada kedua kelas berbeda. Pada kelas eksperimen, siswa yang mendapatkan pendekatan $C R A$ berbasis intuisi peningkatannya tergolong sedang, berbeda dengan siswa pada kelas kontrol yang mendapatkan pembelajaran konvensional peningkatannya tergolong rendah. Hasil penelitian ini didukung oleh hasil penelitian Yuliawati (2011) yaitu peningkatan kemampuan matematik siswa yang menggunakan Pendekatan $C R A$ lebih baik dari pada siswa yang 
menggunakan

pembelajaran

konvensional. Hal tersebut sesuai dengan pernyataan Sumarmo dan Baroody bahwa tahap representasi merupakan bagian dari kemampuan komunikasi matematik. Secara khusus dari mengenai penggunakan pendekatan CRA berbasis intuisi hasil penelitian Azmi (2016) menunjukkan bahwa peningkatan kemampuan analogi matematis siswa yang menggunakan pendekatan CRA berbasis intuisi lebih baik dari pada siswa yang menggunakan pembelajaran konvensional.

Selanjutnya, hasil penelitian ini juga didukung oleh hasil penelitian Fisthi (2013) yang menyatakan model pembelajaran berbasis pada pengembangan intuisi memberikan pengaruh terhadap kemampuan matematik siswa. Dari hasil penelitian tersebut menjadi semakin kuat keterlibatan intiusi dalam pembelajaran matematika. Walaupun teori tersebut hanya mendukung keberhasilan pendekatan CRA dan keterlibatan intuisi secara terpisah-pisah, tetapi telah dibuktikan pada penelitian ini penambahan aspek intuitif pada pendekatan $C R A$ juga mampu meningkatkan kemampuan komunikasi matematik.

Dibandingkan pembelajaran konvensional, pendekatan $C R A$ berbasis intuisi lebih mampu memfasilitasi siswa berlatih dalam mengembangkan kemampuan komunikasi matematik karena aktivitas-aktivitas komunikasi dalam bentuk penjelasan bahasa, simbol, gambar geometri, dan diagram, lebih mudah dipahami jika siswa dipicu dengan pernyataan-pernyataan definisi yang mengedepankan aspek intuitif, menggunakan benda konkret yang membuat siswa dapat mengenal langsung suatu objek sehingga mudah untuk dijelaskan kembali menggunakan bahasa sendiri, melakukan representasi dari benda konkret, dan melakukan pengungkapan ide matematika secara abstrak.

Selain itu, permasalahan yang disajikan pada LKS siswa yang mendapatkan pendekatan $C R A$ berbasis intuisi menuntun siswa untuk aktif dalam melakukan aktivitas intuitif yang mengedepankan feeling dalam menjawab permasalahan. Aktivitas mengidentifikasi benda konkret yang disajikan pada LKS juga membantu siswa agar visualisasi dari benda konkret tersebut dapat terekam secara utuh dipikiran siswa sehingga untuk menuangkan kembali ide atau bentuk dari benda konkret tersebut ke dalam representasi bahasa, simbol, gambar geometri, diagram dan lain sebagainya lebih mudah dilakukan siswa. Selanjutnya, keterlibatan aktivitas abstrak pada LKS juga membantu siswa dalam berkomunikasi matematik secara tertulis untuk menjelaskan ide dan situasi permasalahan menggunakan bahasa matematika yang bersifat abstrak. Kegiatan LKS dari pendekatan $C R A$ berbasis intuisi yang berpusat pada siswa, juga membuat siswa terlibat secara langsung dalam pembelajaran sehinggasiswa benar-benar terfasilitasi untuk melakukan komunikasi matematik baik secara lisan melalui kegiatan diskusi kelompok dan mempresentasi alasan dari jawaban maupun komunikasi tertulis. Hal tersebut merupakan salah satu faktor yang menjadikan kemampuan komunikasi matematik siswa yang mendapatkan pendekatan $C R A$ berbasis intuisi lebih baik dari pada pembelajaran konvensional. Berbeda dengan siswa yang menggunakan pembelajaran konvensional, mereka hanya mendapatkan aktivitas representasi dan abstrak yang diperoleh langsung dari guru dan siswa 
mengamatinya. Ketidakikutsertaan siswa secara langsung dalam proses pembelajaran atau pembelajaran yang berpusat pada guru mengakibatkan siswa sulit dalam mengembangkan kemampuan komunikasi matematik baik secara lisan maupun tertulis.

Berdasarkan tabel 5, 6, dan 7 dari ditinjau berdasarkan tiap-tiap KAM (tinggi, sedang, dan rendah) hasil penelitian ini menunjukkan bahwa peningkatan kemampuan komunikasi matematik antara siswa yang menggunakan pendekatan $C R A$ berbasis intuisi lebih baik secara signifikan dari pada siswa yang menggunakan pembelajaran konvensional. Artinya faktor KAM tinggi, sedang dan rendah merupakan salah satu faktor yang dapat mendorong peningkatan kemampuan komunikasi matematik siswa selain dari faktor pembelajaran yaitu pendekatan $C R A$ berbasis intuisi dan pembelajaran konvensional.

Hal demikian terjadi karena pada pembelajaran matematika menggunakan pendekatan CRA berbasis intuisi, siswa dengan KAM tinggi, sedang, dan rendah sudah dibiasakan mengkomunikasikan ideidenya melalui aktivitas intuitif, benda konkret, visualisasi benda konkret ke dalam bentuk gambar, dan pengerjaan matematik secara abstrak yang sangat membantu siswa dalam penyusunan ide-ide untuk menyelesaikan soal baik secara lisan maupun tertulis. Artinya, dalam mengkomunikasikan matematik khususnya pada materi geometri sangat bergantung pada benda konkret agar proses representasi dan pengerjaan matematika secara abstrak dapat terlaksana dengan maksimal. Hal tersebut diperkuat oleh pernyataan NCTM (dalam Rahmawati, 2013) yaitu salah satu kelebihan dari pendekatan $C R A$ dalam pembelajaran matematika terletak pada intensitas dan kekonkretan yang membantu siswa mempertahankan kerangka kerja dalam memori kerja untuk menyelesaikan masalah. Sebelumnya Suherman telah menyatakan bahwa konsep abstrak yang baru dipahami itu akan mengendap, melekat, dan tahan lama bila belajar melalui berbuat dan pengertian, bukan hanya melalui mengingat-ingat fakta. Artinya pembelajaran matematika menggunakan alat peraga memiliki peran penting dalam menciptakan kekonkretan dan visualisasi bergambar. Hal tersebut tentu berbeda pada siswa kelas konvensional yang tidak mendapatkan tahap konkret secara langsung melainkan hanya mengamati demonstrasi guru dalam menggunakan alat peraga yang mengakibatkan intensitas kekonkretan alat peraga yang mereka amati sulit untuk dipertahankan dalam memori sehingga kemampuan siswa dalam memberikan penjelasan menggunakan bahasa sendiri dan memvisualisasikan benda konkret dalam bentuk gambar geometri dan simbol-simbol berkembang dengan lambat. Hal demikian yang menjadikan peningkatan kemampuan komunikasi matematik siswa pada kelas konvensional pada tiap-tiap KAM tidak lebih baik dari pada kelas pendekatan CRA berbasis intuisi.

Berdasarkan tabel 8, penelitian ini menunjukkan bahwa terdapat perbedaan rerata peningkatan kemampuan komunikasi matematik siswa secara signifikan antar tingkat KAM tinggi, sedang, dan rendah yang menggunakan pendekatan $C R A$ berbasis intuisi. Berdasarkan klasifikasi peningkatan (gain) menurut Hake, peningkatan kemampuan komunikasi matematik siswa pada KAM tinggi tergolong tinggi, berbeda pada KAM sedang dan rendah tergolong sedang. Untuk melihat perbedaan secara berarti 
antar dua kelompok, tidak bisa dilakukan karena tidak terdapat uji lanjutan yang sensitif. Analisis secara deskriptif menunjukkan bahwa KAM tinggi lebih merasakan manfaat dari pembelajaran matematika menggunakan pendekatan CRA berbasis intuisi terhadap kemampuan komunikasi. Mengindikasikan bahwa kategori KAM mempengaruhi peningkatan kemampuan komunikasi matematik siswa yang mendapatkan pendekatan $C R A$ berbasis intuisi. Hal tersebut bisa saja terjadi karena kemampuan dasar atau kemampuan prasyarat matematik siswa pada ketiga KAM yang berbeda-beda. Oleh karena itu guru perlu memperhatikan kondisi kemampuan dasar atau kemampuan prasyarat matematik siswa yang berhubungan dengan aspek komunikasi matematik agar pendekatan $C R A$ berbasis intuisi dapat memfasilitasi kemampuan komunikasi matematik siswa secara maksimal.

\section{KESIMPULAN DAN SARAN}

Berdasarkan hasil penelitian dapat disimpulkan bahwa peningkatan kemampuan komunikasi matematik siswa yang menggunakan pendekatan $C R A$ berbasis intuisi lebih baik dari pada siswa yang menggunakan pembelajaran konvensional ditinjau berdasarkan keseluruhan siswa dan masing-masing KAM siswa (tinggi, sedang, dan rendah). Selain itu terdapat perbedaan peningkatan kemampuan komunikasi matematik siswa antar tingkat KAM (tinggi, sedang, dan rendah) yang menggunakan pendekatan $C R A$ berbasis intuisi.

Pembelajaran matematika menggunakan pendekatan $C R A$ berbasis intuisi hendaknya dapat diterapkan sebagai salah satu alternatif pendekatan pembelajaran untuk meningkatkan kemampuan komunikasi matematik siswa ditinjau berdasarkan keseluruhan siswa, siswa dengan KAM tinggi, siswa dengan KAM sedang, dan siswa dengan rendah. Sebaiknya dalam membiasakan pembelajaran yang berpusat pada siswa seperti menggunakan pendekatan $C R A$ berbasis intuisi, pada pertemuanpertemuan awal siswa diberikan scaffolding dengan bantuan alat peraga pada tiap-tiap kelompok untuk mendengarkan ide dan meminta penjelasan terhadap ide yang mereka kemukakan sehingga mampu menumbuhkan keyakinan mereka untuk memilih ide-ide yang tepat.

Peneliti selanjutnya dapat menggali secara mendalam mengenai kemampuan matematik lainnya menggunakan pendekatan $C R A$ berbasis intuisi atau mengkolaborasinya antara aspek intuitif dengan pendekatan pembelajaran matematika lainnya. Penerapan pendekatan $C R A$ berbasis intuisi untuk meningkatkan kemampuan matematik siswa dapat juga dilakukan pada populasi dan sampel yang lebih besar, ditinjau berdasarkan level sekolah, gaya belajar, jenis kelamin, dan gaya kognitif, serta pada materi pelajaran selain segi empat seperti; segi tiga, lingkaran, bangun ruang, aljabar, dan lain sebagainya.

\section{DAFTAR PUSTAKA}

Asikin, M. 2002. Menumbuhkan Kemampuan Komunikasi Matematika melalui Pembelajaran Matematika Realistik. Prosiding Konferensi Nasional Matematika XI.

Azmi, M. P. 2016. Penerapan Pendekatan ConcreteRepresentational-Abstract $(C R A)$ Berbasis Intuisi untuk Meningkatkan Kemampuan Analogi Matematis Siswa SMP. Jurnal Pengajaran Matematika dan Ilmu Pengetahuan Alam. 
Vol 21. No. 1. DOI: http://dx.doi.org/10.18269/jpmip a.v21i1.655

Cresswell, J. W. 2010. Research Design Pendekatan Kualitatif, Kuantitatif, dan Mixed. (Edisi terjemahan oleh Achmad Fawaid). Yogyakarta: Pustaka Pelajar.

Dahlan, J.A. 2011. Analisis Kurikulum Matematika. Jakarta: Universitas Terbuka

Depdiknas. 2006. Kurikulum Tingkat Satuan Pendidikan (KTSP). Jakarta: Depdiknas.

Fisthi, N. R. 2013. Eksperimentasi Model Pembelajaran Berbasis pada Pengembangan Intuisi terhadap Kemampuan Pemecahan Masalah Matematika Siswa pada Materi Turunan Ditunjau dari Kreativitas Belajar Siswa Kelas XI SMA Negeri 3 Surakarta. Skripsi: Universitas Sebelas Maret Surakarta.

Hake, R. R. 1999. Analyzing ghange/ gain scores. AERA-D American Educational Research Association's Division D, Measurement and Research Methodology, (archived in a somewhat garbled). [online]. Diakses dari http://lists.asu.edu/cgibin/wa?A2=ind $9903 \& \mathrm{~L}=$ aera$\mathrm{d} \& \mathrm{P}=\mathrm{R} 6855$.

Lindawati, S. 2010. Pembelajaran Matematika dengan Pendekatan Inkuiri Terbimbing untuk Meningkatkan Kemampuan Pemahaman dan Komunikasi Matemtis Siswa Sekolah Menengah Pertama. Tesis: Sekolah Pasacasarjana Universitas Pendidikan Indonesia Bandung.
Mahmudi, A. 2009. Komunikasi dalam Pembelajaran Matematika. Jurnal MIPMIPA UNHALU. Vol. 8, No. 1.

Mikrayanti. 2012. Meningkatkan Kemampuan Penalaran dan Komunikasi Matematis Siswa Sekolah Menengah Atas melalui Pembelajaran Berbasis Masalah. Tesis: Sekolah Pasacasarjana Universitas Pendidikan Indonesia Bandung.

NCTM. 2000. Principles and Standards for School Mathematics. Reston, VA: NCTM.

Rahmawati, A. 2013. Penerapan Pembelajaran Matematika melalui Pendekatan CRA (Concrete-RepresentationalAbstract) untuk Meningkatkan Kemampuan Pemecahan Masalah Matematis Siswa SMP. Skripsi: Fakultas Pendidikan Matematika dan Ilmu Pengetahuan Alam Universitas Pendidikan Indonesia Bandung.

Suherman, dkk. 2001. Strategi Pembelajaran Matematika Kontemporer. Bandung: JICA Fakultas Pendidikan Matematika dan Ilmu Pengetahuan Alam Universitas Pendidikan Indonesia.

Sukmana, A. 2011. Profil Berpikir Intuitif Matematik. Laporan Penelitian LPPM: Universitas Katolik Parahyangan Bandung.

Sumarmo, U. 2013. Kumpulan Makalah Berpikir dan Disposisi Matematik Serta Pembelajarannya. Bandung: Fakultas Pendidikan Matematika dan Ilmu Pengetahuan Alam Universitas Pendidikan Indonesia Bandung. 
Suparno, P. 2001. Teori Perkembangan Kognitif Jean Piaget. Yogyakarta: Kanisius.

Trianto. 2011. Mendesain Model Pembelajaran InovatifProgresif: Konsep, Landasan, dan Implementasinya pada Kurikulum Tingkat Satuan Pendidikan. Jakarta: Kencana.

Turmudi. 2008. Landasan Filosofis dan Teoritis Pembelajaran Matematika. Jakarta: Leuser Cita Pustaka.

Turmudi. 2009. Taktik dan Strategi Pembelajaran Matematika Referensi untuk Guru SMK, Mahasiswa, dan Umum. Jakarta: Leuser Cita Pustaka.

Usodo, B. 2012. Karakteristik Intuisi Siswa SMA dalam Memecahkan Masalah Matematika Ditinjau dari Kemampuan Matematika dan Perbedaan Gender. Junal Aksioma Vol. 1.

Walle, J. A. V. 2006. Matematika Sekolah Dasar dan Menengah Jilid I. (Edisi terjemahan oleh Suyono) Jakarta: Erlangga

Witzel, B. S. 2005. Using CRA (Concrete-RepresentationalAbstract) to teach algebra to students with math difficulties in inclusive settings, Laerning Disabilities: A Contemporary Journal. Vol 3. No. 2.

Yuliati, A. 2013. Penerapan Pendekatan ConcreteRepresentational-Abstract (CRA) untuk Meningkatkan Kemampuan Abstraksi Matematis Siswa SMP dalam Belajar Geometri. Skripsi: Fakultas Pendidikan Matematika dan Ilmu Pengetahuan Alam Universitas Pendidikan Indonesia Bandung.

Yuliawati, L. 2011. Pembelajaran Matematika dengan Pendekatan
CRA

(Concrete-

Representational-Abstract)

untuk Meningkatkan

Pemahaman dan Pemecahan

Masalah. Tesis: Sekolah

Pasacasarjana Universitas

Pendidikan Indonesia Bandung. 